\title{
The impact of epididymal proteins on sperm function
}

\author{
Ida Björkgren ${ }^{1}$ and Petra Sipilä2,3 \\ ${ }^{1}$ Department of Molecular and Cell Biology, University of California, Berkeley, California, USA, ${ }^{2}$ Institute of \\ Biomedicine, Research Centre for Integrative Physiology and Pharmacology, Turku, Finland and ${ }^{3}$ Turku Center \\ for Disease Modeling (TCDM), Institute of Biomedicine, University of Turku, Turku, Finland
}

Correspondence should be addressed to P Sipilä; Email: petra.sipila@utu.fi

\begin{abstract}
The epididymis is necessary for post-testicular sperm maturation as it provides the milieu required for spermatozoa to gain the ability for progressive movement and fertilization. In the epididymis the sperm protein, lipid and small RNA content are heavily modified due to interaction with luminal proteins secreted by the epididymal epithelium and extracellular vesicles, epididymosomes. This review focuses on epididymal proteins demonstrated to have an effect on sperm functions, such as motility, capacitation, acrosome reaction, sperm-zona pellucida binding and sperm-egg binding, as well as on embryonic development.

Reproduction (2019) 158 R155-R167
\end{abstract}

\section{Introduction}

After the immature spermatozoa leave testis they acquire the ability to move progressively forward and fertilize the oocyte while being transported through the epididymis. During epididymal sperm maturation, the sperm membrane is under constant remodeling, with attachment and shedding of molecules in a sequential manner. Many of the proteins affecting sperm maturation are secreted into the epididymal lumen where they come into contact with sperm. Another means to deliver proteins as well as other cargo to sperm is the use of extracellular vesicles called epididymosomes. Epididymosomes contain proteins (Nixon et al. 2019), small non-coding RNAs (Reilly et al. 2016, Sharma et al. 2016) and lipids (Girouard et al. 2011) that are delivered to maturing sperm. The exact mechanism by which the epididymosomes deliver their cargo to sperm is still unclear, but it has been suggested that after GPI-anchor-mediated docking, the membranes of epididymosomes and sperm fuse. The other putative, and potentially bi-directional, mechanism of delivering cargo is a formation of transient fusion pores between epididymosomes and sperm (reviewed by Sullivan 2015, Zhou et al. 2018). As a consequence, the sperm proteome (Belleannee et al. 2011, ljiri et al. 2011), lipid composition (Gervasi \& Visconti 2017) and small RNAs (Hutcheon et al. 2017) change during the transit from the proximal initial segment (IS) to the distal cauda.

The elegant work by Bedford and Orgebin-Crist demonstrated the importance of epididymal transit for acquisition of sperm progressive motility and fertilizing capacity already in the 1960's (Bedford 1963,
Orgebin-Crist 1967). The significance of epididymal transit was further confirmed by using genetically modified (GM) mouse models. Knockout (KO) models of Ros 1 (also known as c-ros, (Sonnenberg-Riethmacher et al. 1996, Yeung et al. 1999), leucine-rich repeatcontaining G protein-coupled receptor 4 (LGR4, Hoshii et al. 2007) and Pten (Xu et al. 2014) as well as the transgenic GPX5-Tag2 mice (Sipilä et al. 2002) demonstrated that a lack or dysfunction of the proximal epididymal epithelium leads to male infertility. Many of the above mentioned models exhibited a hairpin bend of the sperm tail caused by a failure of the sperm to regulate the intracellular osmotic pressure. Another frequently seen defect in these models is a change in sperm motility.

GM models in which the gene regulatory programs are disturbed have demonstrated several regulatory pathways necessary for proper epididymal functions and subsequent male fertility. The importance of androgens for epididymal gene expression have been long known, however, as those early experiments involved removal of testes as a source of androgens, the importance of androgen regulation of the given genes for male fertility could not be proven. GM models with conditional androgen receptor (AR) deletion either in developmental precursors of the epididymis, Wolffian duct or IS or caput epididymidis resulted in dedifferentiation of the epithelium, obstruction of the duct and male infertility (Krutskikh et al. 2011, Murashima et al. 2011, O'Hara et al. 2011). AR mutations affecting its functions further confirmed the necessity of AR to epididymal sperm maturation as both, Specificity-affecting AR knockin (SPARKI, Schauwaers et al. 2007, Kerkhofs et al. 2012) 
and SUMOylation-deficient AR (ArKI, Zhang et al. 2019) mice, were present with subfertility or infertility, respectively. Although there were only subtle changes in the epididymal epithelium, both models displayed similar defects in sperm motility. Despite phenotypic similarities, the underlying molecular mechanisms for these defects appear to be different in these mouse models, as the mutations resulted in distinct changes in the gene expression in the epididymides with only a handful of genes changed in both models (Sahu et al. 2014, Zhang et al. 2019).

The miRNA pathway is a well-known posttranscriptional regulator of protein levels. Conditional deletion of Dicer1, a necessary RNAselll enzyme in miRNA processing, from the proximal epididymis resulted in dedifferentiation of the epididymal epithelium demonstrating the importance of miRNA-mediated regulation for epididymal maintenance (Björkgren et al. 2012). Interestingly, lack of Dicer 1 also caused problems in lipid synthesis in the epididymal epithelium and a consequent imbalance of cholesterol and long chain polyunsaturated fatty acids (PUFAs) in the sperm membrane, detachment of the sperm head from the tail and breakage of the acrosome region (Björkgren et al. 2015). Whereas individual epididymal miRNAs have not been linked to sperm dysfunctions, a recent paper described a correlation between unexplained asthenoszoopermia (UA) and dysregulation of five members of the X-linked primate-specific epididymal miRNA cluster. miRNA analysis of semen showed that $13 \%$ of UA patients had lower levels of the miRNAs in question compared to normospermic controls and further, the levels of miRNAs correlated with sperm progressive motility (Qing et al. 2017). Intriguingly, epididymally produced small RNAs, such as tRNA fragments and miRNAs are trafficked from the epididymal epithelium to maturing sperm. They have been shown to transfer epigenetic information to offspring and are essential for normal embryonal development in mice (Sharma et al. 2016, 2018, Conine et al. 2018).

In all the above mentioned models, the epididymal environment changes so drastically that problems in several signaling pathways are likely to contribute to the loss of fertility and thus it is impossible to pinpoint any individual molecule behind defects in sperm function. In this review, we focus on individual epididymal proteins that, although not all epididymis specific, have been shown to affect sperm functional parameters, such as motility and capacitation, and subsequently male fertility (Fig. 1). In addition to the proteins mentioned in this review, there is a large group of proteins that are known to be expressed both in the testis and in the epididymis which are required for sperm function. However, as it is not clear how the epididymal expression of those proteins per se contribute to sperm function, those genes were not included in this review.

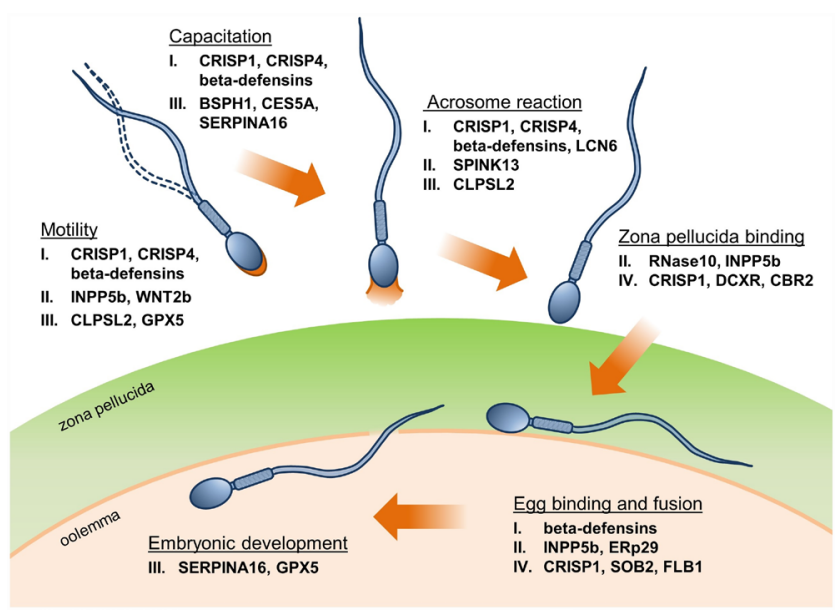

Figure 1 Epididymal proteins affecting different sperm functions during fertilization. I. Epididymal proteins affecting sperm calcium signaling, II. Epididymal proteins modifying sperm proteins, III. Epididymal proteins affecting sperm membrane lipid composition, IV. Epididymal proteins involved in cell-cell interactions.

\section{Epididymal proteins affecting sperm calcium signaling}

The activation of sperm cells in the female reproductive tract mainly relies on an increased influx of calcium ions. The signaling pathway elicited by $\mathrm{Ca}^{2+}$ uptake leads to capacitation of sperm cells with marked increase in protein phosphorylation and the ability of sperm to display hyperactive motility (Yanagimachi 1994, Kirichok et al. 2006). Hyperactivation is characterized as an increase in flagellar bend amplitude and asymmetry which gives the sperm the powerful tail strokes required to reach the egg. In close proximity to the egg, the increased calcium signaling causes the sperm to go through the acrosome reaction (Yanagimachi 1994). The release of the acrosome content reveals egg-binding proteins on the inner acrosome membrane and allows the gametes to fuse. $\mathrm{As} \mathrm{Ca}^{2+}$ signaling drives sperm motility and fertility in the female reproductive tract, ion influx and efflux is highly regulated during sperm maturation. For example, increased levels of the epididymal $\mathrm{Ca}^{2+}$-ATPase isoform 4 (PMCA4a) was detected in bull caudal sperm where it contributes to maintaining the low intracellular $\mathrm{Ca}^{2+}$ levels needed for proper sperm activation (Brandenburger et al. 2011). Furthermore, several proteins secreted by the epididymal epithelium bind to sperm and regulate $\mathrm{Ca}^{2+}$ channels in the sperm membrane. This chapter will describe the proteins/protein families whose main function is to regulate $\mathrm{Ca}^{2+}$ channels in more detail.

\section{CRISP1 and CRISP4}

Members of the CRISP protein family are known to function as ion channel blockers in snake venom and are thought to serve a similar function when expressed 
in the male reproductive tract of mammals (Yamazaki \& Morita 2004). In support of this, the incubation of sperm cells with CRISP1 resulted in reduced activation of the calcium ion cannel CATSPER1 (Ernesto et al. 2015) while CRISP4 was shown to inhibit the transient receptor potential M8 (TRPM8) ion channel in mouse sperm (Gibbs et al. 2011). CRISP1 was first identified in the principal cells and lumen of rat cauda (Cameo \& Blaquier 1976). Here it binds to sperm in two isoforms; $\mathrm{D}$, which is only transiently bound to sperm and released during capacitation, and the smaller isoform E, which is more tightly bound to sperm (Roberts et al. 2008). CRISP1 D is considered to be a decapacitating factor as incubation of rat sperm with exogenous CRISP1 led to reduced protein phosphorylation and inhibition of the acrosome reaction (Roberts et al. 2003). However, this effect seems to be species specific as sperm of Crisp1-knockout mice displayed lower levels of protein tyrosine phosphorylation, although the sperm were able to acrosome react and the mice were fully fertile in normal breeding (Da Ros et al. 2008). Interestingly, the genetic background of the animals also play a role in the severity of the phenotype. While mice of a mixed (129/SvEv and C57Bl/6) background showed reduced levels of tyrosine phosphorylation, a pure $\mathrm{C} 57 \mathrm{Bl} / 6$ background led to defects in both motility and in the induction of the acrosome reaction, although the levels of phosphorylated proteins in capacitated sperm were similar to those of WT mice (Weigel Muñoz et al. 2018).

The phenotype of Crisp1-knockout sperm can partially be compensated for by the presence of CRISP4, which is bound to rodent sperm during transit through the proximal epididymis. Deletion of Crisp4 in mouse led to a reduced induction of the acrosome reaction (Gibbs et al. 2011, Turunen et al. 2012, Hu et al. 2018). The altered acrosome reaction was also thought to affect the interaction of sperm with ZP, as one study showed reduced ZP binding and fertility of knockout sperm (Turunen et al. 2012). In addition, a study by Hu et al. (2018) indicated a role for CRISP4 in capacitation and sperm motility (Hu et al. 2018). The discrepancy between the Crisp4 KO phenotype in the different studies could, like CRISP1, be due to different genetic background of the mice (Weigel Muñoz et al. 2018). This has also been observed in Crisp1/Crisp4-double mutants which show a more prominent, but variable decrease in sperm fertility parameters compared to the single knockout animals. The double $\mathrm{KO}$ generated by Carvajal et al. (2018) led to a subset of mice displaying an inflammation phenotype of the epididymal epithelium which caused decreased viability of sperm. Even without signs of epididymo-orchitis, there was a significantly increased $\mathrm{pH}$ of the epididymal lumen, which could give rise to a multitude of defects during sperm maturation (Carvajal et al. 2018). On the other hand, the double KO generated by Hu et al. only showed signs of epididymal inflammation in older animals, with younger males displaying similar litter sizes as WT mice (Hu et al. 2018). It is interesting to note the significant effect of genetic predisposition to inflammation when considering how the human epididymis only expresses CRISP1, the functional ortholog of both rodent CRISP1 and CRISP4 (Jalkanen et al. 2005, Nolan et al. 2006). Studies of the genetic differences that give rise to the non-infectious epididymitis could therefore also give us new information on human disease and fertility problems.

\section{Beta-defensins}

Similar to the CRISP protein family, DEFB family members are also thought to regulate ion channel activity. Beta-defensins belong to a large family of antimicrobial peptides predominantly expressed in the male reproductive tract, and more precisely, in the epididymis (reviewed in Dorin \& Barratt 2014). In addition to host-defense function, several beta-defensins have been shown to have a role in sperm maturation. SPAG11E (also known as Bin1b) and DEFB15 bind to the sperm head during epididymal transit and induce sperm progressive motility in vitro in rat (Zhou et al. 2004, Zhao et al. 2011). Deletion of mouse Defb41 did not affect male fertility in vivo, but advanced in vitro imaging and analyzing techniques revealed an altered flagellar beat pattern of capacitated Defb41knockout sperm and consequently altered sperm velocity and a reduction in oocyte binding (Björkgren et al. 2016). The mild phenotypic changes in the mouse and rat models introduced above might be due to compensatory functions of other beta-defensins present in the epididymal fluid. Indeed, a series of knockouts of rat beta-defensins, namely Defb23, Defb26 and Defb42, demonstrated that as single gene knockouts, they did not cause any change in sperm motility or male fertility, whereas animals carrying double, Defb23/26, or triple, Defb23/26/42, gene deletions were subfertile and demonstrated decreased sperm motility, precocious capacitation and increased spontaneous acrosome reaction (Zhang et al. 2018). Similarly, a concurrent deletion of nine mouse beta-defensins, Defb1, Defb50, Defb2, Defb10, Defb9, Defb11, Defb15, Defb35 and Defb13 from the beta-defensin gene cluster on chromosome 8, caused reduced sperm motility and increased fragility with disintegration of the microtubule structure of Defb $\Delta 9$ sperm. Furthermore, Defb $\Delta 9$ sperm displayed precocious capacitation, increased spontaneous acrosome reactions and reduced ability to bind to oocytes (Zhou et al. 2013). Moreover, in contrast to Defb1-knockout mice which do not have a reproductive phenotype (Morrison et al. 2002), significantly reduced levels of human DEFB1 were found in sperm of infertile men with low sperm motility (Diao et al. 2014). This suggests that the larger rodent 
beta-defensin family have more overlapping functions compared to their human homologs.

The antimicrobial properties of beta-defensins are due to the ability of these cationic molecules to bore holes into phospholipid membranes (Hall et al. 2007). This mechanism has also been shown to activate L-type $\mathrm{Ca}^{2+}$ channels (Bateman et al. 1996). Studies with SPAG11E indicate that it is activating sperm $\mathrm{Ca}^{2+}$ channels, leading to $\mathrm{Ca}^{2+}$ influx into sperm (Zhou et al. 2004). In addition, DEFB1 was shown to interact with chemokine receptor type 6 (CCR6) and thereby triggering a rise in intracellular $\mathrm{Ca}^{2+}$ (Diao et al. 2014). In contrast, both animal models with several beta-defensins deleted, showed increased intracellular $\mathrm{Ca}^{2+}$ content of the sperm, which was suggested to lead to premature hyperactivation and spontaneous acrosome reaction of the knockout sperm (Zhou et al. 2013, Zhang et al. 2018). Thus, the role of DEFBs in controlling the function of $\mathrm{Ca}^{2+}$ channels is still unclear. It is however possible that different DEFBs regulate different $\mathrm{Ca}^{2+}$ channels with varying outcomes. Moreover, the molecular mechanism of sperm $\mathrm{Ca}^{2+}$ channel regulation is unsolved and whether the holeboring ability of beta-defensins has a role here remains to be studied.

A distinctive mode of action has been described for DEFB126 (mouse and rat homolog DEFB22). DEFB126 is produced in the corpus epididymidis, from where it is secreted, binds to the sperm surface and forms an integral part of the sperm glycocalyx (Tollner et al. 2012). It has a highly glycosylated C-terminal tail that provides a negatively charged coating for sperm, necessary for spermatozoa to swim efficiently in the cervical mucus in macaques (Tollner et al. 2008a). When sperm reaches the oviduct, DEFB126 is critical for attachment of the sperm to the oviductal epithelium. The removal of DEFB126 from the sperm membrane was shown to be necessary for sperm release from the oviductal reservoir at the time of ovulation, and conditions simulating periovulatory oviductal fluid quickly induced both shedding of DEFB126 from the sperm membrane and capacitation (Tollner et al. 2008b). In addition, experimental data suggest that the sialylated oligosaccharides of DEFB126 on the sperm glycocalyx effectively mask other protein components on the sperm surface, protecting sperm from immune surveillance in the female reproductive tract (Tollner et al. 2012). Interestingly, two human frame-shift mutations of DEFB126 have been shown to affect male fertility. Mutation rs11468374 described by Tollner et al. affected the ability of sperm to penetrate the cervical mucus, whereas other sperm parameters, including motility were unchanged. Men homozygous for this frame-shift mutation were found to have a reduced chance of successful conception (Tollner et al. 2011). In addition, another described DEFB126 mutation, rs11467497, has significant association with male infertility, without affecting sperm motility (Duan et al. 2015).

\section{LCN6}

The epididymis of rodents and humans express several lipocalins (LCNs) belonging to a highly conserved gene cluster (Suzuki et al. 2004). Lipocalins are extracellular proteins that are able to transport small hydrophobic molecules such as steroids and lipids (Flower 1996). Although LCN proteins are hypothesized to be important for sperm maturation, so far only LCN6 is known to play a role in sperm function. Expression of Lcn 6 in the proximal epididymis leads to binding of the protein to the postacrosomal region in human and mouse sperm cells (Hamil et al. 2003, Yin et al. 2018). Studies of an Lcn6-knockout mouse model showed an important function in regulating $\mathrm{Ca}^{2+}$ influx of sperm cells. Although Lcn6 ablation led to $\mathrm{Ca}^{2+}$ overload of sperm cells and, consequently, an increased spontaneous acrosome reaction, the knockout males were fertile and the sperm were motile and able to capacitate in a similar manner to WT sperm (Yin et al. 2018). An explanation for this could be that a majority of sperm cells were still acrosome intact after in vitro capacitation which would indicate either a minor role for LCN6 or a functional substitution of the protein with other lipocalins still present in the epididymis. Thus, further studies are needed to show how different lipocalins interact during sperm maturation and what the mechanism of LCN6 regulation of ion channel(s) entails.

\section{Epididymal proteins modifying sperm proteins}

Several posttranslational modifications (PTMs), such as phosphorylation, glycosylation (Baker 2016) and O-GlcNAcylation (Tourzani et al. 2018) of sperm proteins occur during epididymal sperm maturation. The importance of the PTMs is still unclear, but as sperm are transcriptionally silent cells, PTMs provide a means of controlling the protein activity in sperm. As an example of changes in protein phosphorylation status during epididymal transit, the cytoplasmic domain of IZUMO1, a protein necessary for sperm-egg fusion, becomes heavily phosphorylated in the epididymis. It has been postulated that in the case of IZUMO1, phosphorylation would play a role in re-location of the protein in the sperm membrane or during sperm-oocyte fusion (Baker et al. 2012). Another example of a protein modified during epididymal transit is ADAM3 (also known as cyritestin), which is required for gamete interaction (Shamsadin et al. 1999, Inoue et al. 2005). A lack of epididymal cleavage of sperm surface ADAMs (ADAM3, -2, and -6) does not only reduce the activity of the enzymes but also the attachment of the protein complex to the sperm surface (Nishimura et al. 2007, Han et al. 2009, Krutskikh et al. 2012). In the following chapter we will describe proteins known to affect sperm function via PTMs during epididymal maturation, for more information about the PTMs the reader is directed to the following excellent reviews (Baker 2016, Brohi \& Huo 2017). 


\section{RNase10}

The cleavage of ADAMs in the epididymis is segment specific, as seen in the case of RNase10, an enzyme expressed in the most proximal region of the mouse and boar epididymides (Penttinen et al. 2003, Castella et al. 2004). Although RNase10 lacks ribonuclease activity, it was shown to cleave the immature form of ADAM6 and thereby retain the protein in complex with ADAM3 (Krutskikh et al. 2012). In RNase10-knockout mice, the consequent loss of ADAM3 from spermatozoa led to a significantly reduced fertility although the sperm cells displayed normal motility, capacitation and acrosome reaction. However, they were not able to fully adhere to ZP although they showed increased ability to fuse with and fertilize eggs in vitro. The study by Krutskikh et al. (2012) also propose that the IS-specific expression and secretion of the enzyme could lead to cleavage of additional sperm proteins (Krutskikh et al. 2012).

\section{INPP5b}

Another protein important for sperm maturation and ADAM cleavage is the inositol polyphosphate 5-phosphatase INPP5b. Instead of a direct proteolytic activity on sperm cells, INPP5b was hypothesized to regulate the availability of proteases for ADAM2 and ADAM3 cleavage in the epididymis (Hellsten et al. 2001). Although the phosphatase is expressed in the testis as well as the epididymis, a spermatid-specific knockout of Inpp5b did not cause similar defects as those observed in the full knockout animals where spermatozoa displayed both reduced motility and an inability to bind to ZP and fuse with the egg (Hellsten et al. 2001). The phenotype was linked to a defect in ADAM2 cleavage during transit of sperm from caput to cauda. However, mouse of different background display phenotypes of varied severity and a later study by Marcello and Evans (Marcello \& Evans 2010) showed little correlation between ADAM2 and ADAM3 processing and the fertility phenotype, indicating that INPP5b is able to regulate the cleavage of additional proteins during sperm maturation. In addition, since neither the Inpp5b nor the RNase10-knockout mice showed complete inhibition of ADAM cleavage, other, still unknown, proteins are probably also utilized for this process.

\section{Wnt signaling}

An elegant example of how modification of sperm proteins during epididymal transit affect sperm motility came from studies by Koch and colleagues who demonstrated that epididymal Wnt is an important regulator of sperm motility through inhibition of glycogen synthase kinase-3 (GSK3) (Koch et al. 2015). It has been known for over 20 years that inhibition of Ser/Thr-protein phosphatase I catalytic subunit gamma 2, PPP1CC2 (previously known as PP1 $\gamma 2$ ), activity in caput sperm induces motility (Vijayaraghavan et al. 1996). The early studies with bovine sperm suggested that in caput sperm, a high activity of GSK3 inhibits the activity of the PPP1CC2 inhibitor, protein phosphatase 1 , regulatory inhibitor subunit 2, PPP1R2 (previously known as I2). In cauda sperm, the reduced activity of GSK3 results in activation of PPP1R2, subsequent inactivation of PPP1CC2 and induction of sperm motility (Vijayaraghavan et al. 1996). A more recent study in mouse further demonstrated that three PPP1CC2 inhibitors, PPP1R2, -R7 and -R11, are present in mouse sperm where they co-localize with PPP1CC2 in the head and the principal piece. In immotile caput sperm, PPP1R2 and PPP1R7 are not bound to PPP1CC2, whereas in motile caudal sperm, all three inhibitors are bound as heterodimers or heterotrimers. The binding of the inhibitors to PPP1CC2 is affected by their phosphorylation, and it is known that GSK3 is the protein kinase phosphorylating PPP1R2. Moreover, in infertile GSK3-knockout mice, PPP1CC2 is not associated with the inhibitors (Goswami et al. 2019).

How does the epididymis regulate this sperm intrinsic signaling pathway? Here the epididymal Wnt signaling steps in. Multiple Wnt ligands are expressed in the epididymis andWnt2b was also found in epididymosomes (Koch et al. 2015). Wnts signal through two co-receptors, Frizzled (FZD) and low-density lipoprotein receptorrelated 6 (LRP6), and epididymosomes were found to activate LRP6 at the sperm membrane ex vivo. The Wnt regulator cyclin Y-like 1 (Ccny/1) is highly expressed in germ cells, and Ccny/1-knockout male mice are infertile due to immotile and malformed spermatozoa. Ccny-dependent Wnt signaling is known to regulate GSK3 activity. The phosphorylation of inhibitor PPP1R2 was shown to be greatly increased in Ccnyl-knockout sperm, likely leading to higher PPP1CC2 activity and hence reduced protein phosphorylation. Indeed, it was shown that total phospho-serine was markedly reduced in Ccnyl1-knockout sperm (Koch et al. 2015). A recent study, where Wntless, a membrane protein required for all WNT protein secretion, was conditionally deleted from mouse caput epididymidis failed to demonstrate any effects on sperm motility and male fertility even though WNT10A and WNT2b proteins were significantly reduced in the epididymal luminal fluid (Cheng et al. 2018). This difference might have multiple explanations; incomplete recombination by the Crerecombinase used, expression of WNTs and WNTLESS in other epididymal segments and most of all, presence of WNTs in the epididymosomes that deliver their cargo directly to sperm thus bypassing the need of secretion of WNTs to the epididymal fluid of caput. Altogether these findings suggest the following mechanism controlling epididymal sperm motility: epididymal Wnts in epididymosomes regulate sperm GSK3 activity via LPR6 and Ccnyl1. In the presence of inactive GSK3, the PPP1CC2 inhibitors, PPP1R2 and -R7, bind to PPP1CC2 


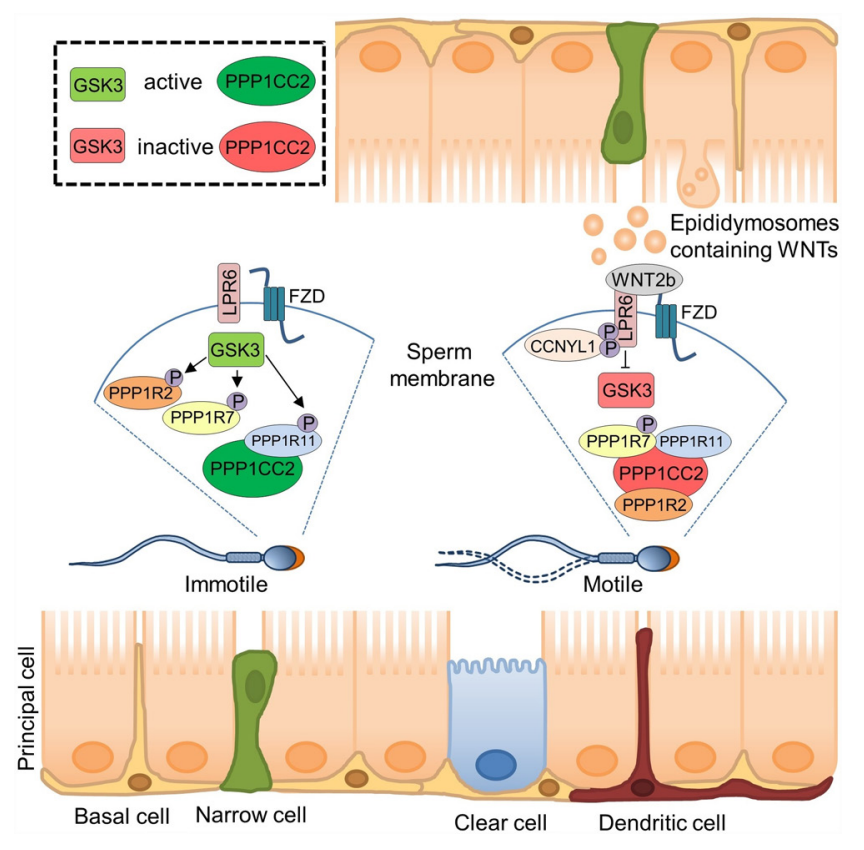

Figure 2 Schematic of epididymal Wnt-mediated regulation of sperm motility. Epididymal epithelial cells secrete epididymosomes that contain WNT proteins. In the absence of Wnt signaling, sperm glycogen synthase kinase-3 (GSK3) is active and phosphorylates the PPP1CC2 inhibitors PPP1R2, -R7 and -R11 and thus PPP1CC2 remains active. When epididymal WNTs activate the receptors Frizzled (FZD) and low-density lipoprotein receptor-related 6 (LRP6) primed by cyclin Y-like 1 (CCNYL1), GSK3 is inactivated allowing PPP1R2 and -R7 binding to PPP1CC2 and thus rendering the PPP1CC2 inactive. When PPP1CC2 is inactivated, total phospho-serine levels increase and the spermatozoon becomes fully motile.

rendering it inactive, hence leading to increases in total phospho-serine in sperm and increased motility (Fig. 2).

\section{SPINK13}

The epididymis-specific SPINK13 (serine peptidase inhibitor, Kazal type 13) is a protease inhibitor needed for proper sperm maturation. Several members of the SPINK protein family are highly expressed in the epididymis (Jalkanen et al. 2006) and in rats Spink13 is mainly found in the IS and with lower levels in more distal segments (Ma et al. 2013). The protein was secreted into the epididymal lumen where it localized to the acrosome of maturating sperm cells. Analyses of sperm after RNAi knockdown of Spink13 showed increased spontaneous acrosome reaction, although no difference in capacitation was detected (Ma et al. 2013). Interestingly, comparison between SPINK13 and LCN6 models revealed that Lcn6-knockout sperm displayed much higher levels of spontaneous acrosome reaction compared to sperm lacking SPINK13. However, Spink13 downregulation gave rise to a significant reduction in male fertility both in vitro and in vivo, while the Lcn6 KO did not show any fertility phenotype (Ma et al. 2013,
Yin et al. 2018). This could of course be due to the different rodent species used for the studies, but could also indicate an additional function for SPINK13 in sperm-egg interaction. A number of serine proteases have been identified on sperm acrosome, however, in vivo target proteases of SPINK13 have not yet been identified.

\section{ERp29}

The sperm endoplasmic reticulum protein 29 (ERp29) in rodents is hypothesized to serve a role in gamete interaction. ERp29 belongs to the protein disulfide isomerase (PDI) family which causes a conformational change in proteins and thereby promotes cell-cell interaction. Among others, ERp29 can facilitate polyomavirus infection by changing the viral protein structure and stimulate penetration of the virus into the host cells endoplasmic reticulum (Magnuson et al. 2005). In both mice and rats, ERp29 is detected in the epididymal epithelium with increased expression from caput to cauda and a subsequent increase in protein levels of caudal sperm (Guo et al. 2007, Ying et al. 2010). The motility and acrosome reaction of mouse sperm cells were not affected by incubation with an antibody against ERp29. However, the fertilization capacity of sperm was significantly reduced with increased concentration of the antibody (Ying et al. 2010). To further support the role of ERp29 in sperm-egg interaction the protein was relocated to the equatorial segment, the initial site of gamete fusion, after the acrosome reaction. Thus, similar to its role in viral infections, ERp29 was hypothesized to cause thiol-disulfide exchange in proteins on the sperm surface and thereby trigger binding to receptors on the egg (Ying et al. 2010).

\section{Epididymal proteins affecting sperm membrane lipid composition}

When spermatozoa enter the female reproductive tract, an efflux of cholesterol from the sperm membrane precedes the influx of $\mathrm{Ca}^{2+}$ required for capacitation. The change gives rise to an increased fluidity of the sperm membrane which is needed to prepare the cells for fertilization of the egg (Travis \& Kopf 2002). However, already during maturation in the epididymis the sperm membrane is modified by incorporation of unsaturated lipids and a gradual removal of cholesterol. Sperm from most mammalian species experience an approximate $50 \%$ reduction in cholesterol levels when moving from the proximal epididymal segments to cauda (Parks \& Hammerstedt 1985, Hall et al. 1991, Awano et al. 1993, Rejraji et al. 2006). Although this results in a more fluid membrane, the epididymal environment keeps the sperm in a quiescent state throughout transit and storage. This is achieved, in part, by the acidic $\mathrm{pH}$ of the luminal fluid but also by binding of so called decapacitation 
factors to the sperm surface (Nixon et al. 2006, Shum et al. 2011). When in transit to the fallopian tube, the inhibiting factors are released and the sperm is able to achieve capacitation.

\section{Binder of SPerm protein homolog 1}

A protein that influences the lipid content of the sperm membrane and in turn capacitation is Binder of SPerm protein homolog 1 (BSPH1). The protein was first discovered in the seminal plasma of bulls (Esch et al. 1983, Manjunath 1984) and, later, homologous genes were found to be expressed in the bovine (BSPH1, Han et al. 2009), mouse (Bsph1) and human (BSPH1) epididymis (Fan et al. 2006, Lefebvre et al. 2007). During epididymal transit and while still bound to sperm, BSPH1 is said to prevent movement of lipids in the sperm membrane and thereby protect the sperm from premature capacitation. When the sperm cell reaches the oviduct it comes in contact with high-density lipoproteins (HDLs) which interact with BSPH1 and can cause release of phospholipids and cholesterol from the sperm membrane (Plante \& Manjunath 2015). This was shown for both mouse and human sperm, which displayed increased protein tyrosine phosphorylation after incubation with recombinant BSPH1. However, no change in sperm acrosome reaction or motility was detected (Plante et al. 2012, 2014).

\section{CES5A}

One factor that is hypothesized to play a role in maturation of the sperm lipid membrane is the carboxylesterase CES5A, previously known as CES7. The protein was first detected in rat epididymis where it is secreted into the lumen of corpus and cauda (Zhang et al. 2009). Knockdown of Ces5a by RNAi injection into rat cauda, caused reduced levels of protein tyrosine phosphorylation during capacitation and a reduced fertility both in vitro and in vivo (Ru et al. 2015). The function of CES5A in sperm capacitation is not fully understood as it does not seem to have a direct interaction with spermatozoa in the epididymal lumen but is instead thought to alter the lipid content of the luminal fluid and then indirectly that of the sperm membrane (Zhang et al. 2009, Ru et al. 2015). Expression of CES5A is tightly regulated by the epididymis specific miRNA-like small RNA HongrES2 (mil-HongrES2, Ni et al. 2011). Considering this study and how the ablation of miRNA processing in the proximal segment of the mouse epididymis caused a significant change in epididymal lipid production and animal fertility (Björkgren et al. 2015), it would be interesting to see if miRNAs of the distal epididymis have a similar effect on the lipid content of the sperm membrane.

\section{SERPINA16}

A decapacitating factor expressed by the principal cells of mouse, rat and guinea pig cauda is Serpina16, also known as HongrES1 in rat and mHong 1 in mouse (Hu et al. 2002, 2012, Ni et al. 2009). It is secreted into the epididymal lumen and bound to sperm, where the protein is hypothesized to inhibit the action of cholesterol acceptors. Incubation of HongrES1-knockdown sperm with bovine serum albumin (BSA) caused an increased membrane fluidity and premature protein tyrosine phosphorylation (Zhou et al. 2008). In addition, the RNAi knockdown of HongrES1 led to a reduced number of progeny and, interestingly, an increased number of fetuses that displayed developmental defects (Zhou et al. 2008). Serpina16 belongs to the Serpin family of protease inhibitors. However, its amino acid sequence differs from that of traditional inhibitory serpins and the protein function and its role in sperm capacitation remains unknown (Hu et al. 2002).

\section{CLPSL2}

Colipase-like 2 (Clps/2) is specifically expressed in human (Li et al. 2008) and mouse (Oh et al. 2006) caput epithelium from where it is secreted and binds to sperm cells (Lu et al. 2018). Localization of the protein to the acrosome region and principal piece of mouse sperm is important for the integrity of the acrosome region and the progressive motility of spermatozoa (Lu et al. 2018). In addition, the injection of shRNA lentivirus particles against Clps/2 caused a significant decrease in sperm number as well as reduced fertility of male mice, both in vitro and in normal breeding (Lu et al. 2018), which was mainly accredited to the reduced integrity of the sperm membrane. Unlike its relative, the pancreatic colipase, CLPSL2 is not thought to function in lipid hydrolysis but instead in remodeling of the sperm membrane lipid profile (Lu et al. 2018). This could also affect additional sperm functions, for example capacitation, which also requires changes in the lipid content of the membrane.

\section{GPX5}

The glutathione peroxidase GPX5 is highly expressed in the epididymis of mammals, where it is secreted into the lumen and able to protect sperm from lipid peroxidation. When Gpx5 was ablated from the mouse epididymis, it did not lead to any fertility phenotype at younger age, but breeding of 1 -year-old males and older resulted in more miscarriages and developmental defects than for WT males (Chabory et al. 2009). This was hypothesized to be the result of increased DNA fragmentation in Gpx5 KO sperm. As a result of Gpx5 ablation, the mice displayed increased expression of other glutathione peroxidases and catalase in cauda, which could partially compensate for the observed phenotype (Chabory et al. 2009). Interestingly, 
in studies of a double knockout for Gpx5 and the sperm nuclear Gpx4, the male mice showed a much higher compensatory expression of ROS scavengers, which allowed them to sire the same number of pups as wild type mice, regardless of age (Noblanc et al. 2012). Similar to mice, boars with lower levels of GPX5 in their seminal plasma showed reduced farrowing rates due to increased oxidative stress (Barranco et al. 2016). However, unlike mice, Gpx5 is expressed throughout the genital tract of boars and is also required for proper motility of sperm cells, which could further influence the observed difference in breeding (Barranco et al. 2016). Overall, larger mammals display an expression pattern of Gpx5 that differs from that of rodents (Grignard et al. 2005), with humans having much lower expression levels than other species (Hall et al. 1998). Further studies are thus needed to clarify if and how the antioxidant affect the fertility of these males.

\section{Epididymal proteins involved in cell-cell interactions}

The epididymis secretes several proteins involved in cell-cell interaction that, after binding to spermatozoa, allow the sperm to recognize and fertilize the egg. The process of sperm-egg fusion share common features with that of fusion between a virus and its host cell, where an initial binding of viral proteins with receptors on the cell surface is required before the two membranes can merge (Stein et al. 2004). Similarly to viral infections, sperm cells are known to utilize a number of proteins to facilitate the recognition and binding of gametes. Although blocking their function does not prevent fertilization completely, these proteins work synergistically to promote sperm-egg membrane fusion.

\section{CRISP1}

In addition to its role in calcium signaling, CRISP1 is also required for gamete interaction. Incubation with recombinant human CRISP1 completely blocked sperm binding to zona pellucida (ZP), as the recombinant protein was hypothesized to occupy the CRISP1 epitopes of ZP3 (Maldera et al. 2014). The sperm cells were already capacitated and only exposed to the protein during the short time of ZP interaction, thus excluding any effect the inhibitor could have on the role of CRISP1 during sperm capacitation (Da Ros et al. 2008, Maldera et al. 2014). After the sperm binds to ZP and goes through the acrosome reaction, rat CRISP1 is relocated from the dorsal part of the acrosome to the region destined for gamete fusion, the equatorial segment of the sperm cell (Rochwerger \& Cuasnicu 1992). Complementary sites across the murine and human egg membrane are able to directly bind CRISP1 . However, CRISP1 does not affect the initial binding of sperm, as incubation of eggs with recombinant CRISP1 protein did not lead to a reduced number of bound sperm cells but only prevented the penetration of the egg by spermatozoa (Cohen et al. 2000, 2001, Busso et al. 2007). Because CRISP1 does not contain any hydrophobic domains (Brooks 1987), the protein was hypothesized to provide the interaction needed for membrane fusion instead of having a direct role in the process (Cohen et al. 2000).

\section{DCXR}

Dicarbonyl/L-xylulose reductase (DCXR, also known as sperm surface protein $\mathrm{P} 34 \mathrm{H}$ ) is, as the name implies, an enzyme able to catalyze the reduction of several different aromatic dicarbonyl compounds and sugars (Wang \& Van Eys 1970, Nakagawa et al. 2002). However, it can also serve in a non-catalytic fashion by interacting with proteins such as cadherins and catenins, and thereby influence cell-cell adhesion (Cho-Vega et al. 2007). In humans, the expression of DCXR in male reproductive tissues increases from testis to the distal segments of the epididymis, with the highest expression observed in corpus epididymis. Similarly, DCXR protein levels increase on the acrosome of spermatozoa during epididymal transit (Légaré et al. 1999). Incubation of sperm with an antibody against DCXR greatly inhibited binding to ZP, although the ability to bind to and fuse with ZP-free eggs was not reduced (Boué et al. 1994). The molecular mechanism of DCXR during sperm-ZP interaction is not known, but as it is bound to the sperm surface, it may have a similar function as that observed in epithelial cell-cell interaction. Interestingly, sperm samples from infertile patients often show lower levels of DCXR (Boué \& Sullivan 1996, Moskovtsev et al. 2007) and a study using DCXR-negative sperm cells in IVF did not lead to any fertilized eggs (Sullivan et al. 2006), a strong indication of the importance of this protein in human reproduction.

The hamster and bovine epididymides express another member of the dehydrogenase/reductase family, carbonyl reductase 2 (Cbr2), a protein not found in primates or humans (Sullivan \& Robitaille 1989, Frenette \& Sullivan 2001). Similar to DCXR, hamster CBR2 (also known as P26h) and bovine CBR2 (also known as P25b) are tethered to spermatozoa by a GPI-anchor during sperm maturation and are known to be involved in sperm-ZP binding (Bérubé \& Sullivan 1994, Légaré et al. 1999, Parent et al. 1999, Frenette \& Sullivan 2001). Especially, inhibition of the enzymatic activity of hamster CBR2 was shown to reduce binding capacity of sperm to ZP by almost 50\% (Montfort et al. 2002). However, the enzyme does seem to serve species specific functions, as the mouse CBR2 (also known as MLCR or AP27) has not yet been shown to participate in any fertilization event (Bégin et al. 1995). 


\section{SOB2 and FLB1}

In a valiant effort to identify additional proteins involved in sperm-oocyte interaction, Boué et al. incubated human sperm with monoclonal antibodies against their surface proteins (Boué et al. 1992). This led to the discovery of the so-called sperm-oocyte-binding antigen 2 (SOB2) and FLB1, which are specifically expressed in caput and corpus of human epididymis, with additional expression of FLB1 in the defers (Boué et al. 1995, Lefèvre et al. 1997). During maturation, SOB2 first displays a diffuse localization over the sperm head which becomes restricted to the post-acrosomal and neck area in corpus (Lefèvre et al. 1997). FLB1, in turn, was shown to be secreted by hamster epididymal cells in vitro, from where it is thought to be transferred to the equatorial region of sperm cells (Boué et al. 1995). When incubating spermatozoa with antibodies against SOB2 or FLB1, the sperm showed a significantly reduced ability to bind to zona-free hamster eggs even though sperm motility and acrosome reaction were unaffected (Boué et al. 1995, Lefèvre et al. 1997). Although the SOB2 antibody detected proteins in rat, hamster and rabbit sperm (Lefèvre et al. 1997), a similar function to that of human SOB2 has not to our knowledge been detected in these species.

\section{Conclusions}

The essential role of the epididymis in male fertility, as the place where sperm obtain their full capacity for fertilization, has already been known for a long time. However, many of the earlier models used to demonstrate this effect were so crude that the function of individual molecules in the maturation process could not be discerned. During recent years, several elegant studies have made more detailed analyses of the important role of the epididymis in attaining proper sperm function. In this review, we have introduced studies of 16 such proteins, protein families and signaling pathways to the reader. The CRISPR/Cas9 gene-editing technology is expected to speed up the identification and functional validation of epididymal proteins involved in male fertility. Epididymis-specific conditional models are further anticipated to reveal the importance of numerous genes with expression in both the epididymal epithelium and in testicular germ cells. These studies will be of utmost importance for understanding the molecular basis of sperm fertilizing ability, especially in regards to the alarming decline in male fertility observed in Western countries.

\section{Declaration of interest}

The authors declare that there is no conflict of interest that could be perceived as prejudicing the impartiality of this review.

\section{Funding}

This research did not receive any specific grant from any funding agency in the public, commercial or not-for-profit sector.

\section{References}

Awano M, Kawaguchi A \& Mohri H 1993 Lipid composition of hamster epididymal spermatozoa. Reproduction 99 375-383. (https://doi. org/10.1530/jrf.0.0990375)

Baker MA 2016 Proteomics of post-translational modifications of mammalian spermatozoa. Cell and Tissue Research 363 279-287. (https://doi.org/10.1007/s00441-015-2249-x)

Baker MA, Hetherington L, Weinberg A, Naumovski N, Velkov T, Pelzing M, Dolman S, Condina MR \& Aitken RJ 2012 Analysis of phosphopeptide changes as spermatozoa acquire functional competence in the epididymis demonstrates changes in the post-translational modification of Izumo1. Journal of Proteome Research 11 5252-5264. (https://doi. org/10.1021/pr300468m)

Barranco I, Tvarijonaviciute A, Perez-Patiño C, Vicente-Carrillo A, Parrilla I, Ceron JJ, Martinez EA, Rodriguez-Martinez H \& Roca J 2016 Glutathione peroxidase 5 is expressed by the entire pig male genital tract and once in the seminal plasma contributes to sperm survival and in vivo fertility. PLOS ONE 11 e0162958. (https://doi.org/10.1371/journal. pone.0162958)

Bateman A, MacLeod RJ, Lembessis P, Hu J, Esch F \& Solomon S 1996 The isolation and characterization of a novel corticostatin/defensin-like peptide from the kidney. Journal of Biological Chemistry 27110654 10659. (https://doi.org/10.1074/jbc.271.18.10654)

Bedford JM 1963 Changes in the electrophoretic properties of rabbit spermatozoa during passage through the epididymis. Nature 2001178 1180. (https://doi.org/10.1038/2001178a0)

Bégin S, Bérubé B, Boué F \& Sullivan R 1995 Comparative immunoreactivity of mouse and hamster sperm proteins recognized by an anti-P26h hamster sperm protein. Molecular Reproduction and Development 41 249-256. (https://doi.org/10.1002/mrd.1080410216)

Belleannee C, Belghazi M, Labas V, Teixeira-Gomes AP, Gatti JL, Dacheux JL \& Dacheux F 2011 Purification and identification of sperm surface proteins and changes during epididymal maturation. Proteomics 11 1952-1964. (https://doi.org/10.1002/pmic.201000662)

Bérubé B \& Sullivan R 1994 Inhibition of in vivo fertilization by active immunization of male hamsters against a $26-k D a$ sperm glycoprotein. Biology of Reproduction 51 1255-1263. (https://doi.org/10.1095/ biolreprod51.6.1255)

Björkgren I, Saastamoinen L, Krutskikh A, Huhtaniemi I, Poutanen M \& Sipilä P 2012 Dicer1 ablation in the mouse epididymis causes dedifferentiation of the epithelium and imbalance in sex steroid signaling. PLOS ONE 7 e38457. (https://doi.org/10.1371/journal.pone.0038457)

Björkgren I, Gylling H, Turunen H, Huhtaniemi I, Strauss L, Poutanen M \& Sipilä P 2015 Imbalanced lipid homeostasis in the conditional Dicer1 knockout mouse epididymis causes instability of the sperm membrane. FASEB Journal 29 433-442. (https://doi.org/10.1096/fj.14-259382)

Björkgren I, Alvarez L, Blank N, Balbach M, Turunen H, Laajala TD, Toivanen J, Krutskikh A, Wahlberg N, Huhtaniemi I et al. 2016 Targeted inactivation of the mouse epididymal beta-defensin 41 alters sperm flagellar beat pattern and zona pellucida binding. Molecular and Cellular Endocrinology 427 143-154. (https://doi.org/10.1016/j. mce.2016.03.013)

Boué F \& Sullivan R 1996 Cases of human infertility are associated with the absence of $\mathrm{P} 34 \mathrm{H}$ an epididymal sperm antigen. Biology of Reproduction 54 1018-1024. (https://doi.org/10.1095/biolreprod54.5.1018)

Boué F, Lassalle B, Duquenne C, Villaroya S, Testart J, Lefevre A \& Finaz C 1992 Human sperm proteins from testicular and epididymal origin that participate in fertilization: modulation of sperm binding to zona-free hamster oocytes, using monoclonal antibodies. Molecular Reproduction and Development 33 470-480. (https://doi.org/10.1002/ mrd.1080330414)

Boué F, Bérubé B, De Lamirande E, Gagnon C \& Sullivan R 1994 Human sperm-zona pellucida interaction is inhibited by an antiserum against a hamster sperm protein. Biology of Reproduction 51 577-587. (https:// doi.org/10.1095/biolreprod51.4.577) 
Boué F, Duquenne C, Lassalle B, Lefevre A \& Finaz C 1995 FLB1, a human protein of epididymal origin that is involved in the sperm-oocyte recognition process. Biology of Reproduction 52 267-278. (https://doi. org/10.1095/biolreprod52.2.267)

Brandenburger T, Strehler EE, Filoteo AG, Caride AJ, Aumüller G, Post H, Schwarz A \& Wilhelm B 2011 Switch of PMCA4 splice variants in bovine epididymis results in altered isoform expression during functional sperm maturation. Journal of Biological Chemistry 286 7938-7946. (https://doi. org/10.1074/jbc.M110.142836)

Brohi RD \& Huo LJ 2017 Posttranslational modifications in spermatozoa and effects on male fertility and sperm viability. Omics 21 245-256. (https://doi.org/10.1089/omi.2016.0173)

Brooks DE 1987 Androgen-regulated epididymal secretory proteins associated with post-testicular sperm development. Annals of the New York Academy of Sciences 513 179-194. (https://doi. org/10.1111/j.1749-6632.1987.tb25008.x)

Busso D, Cohen DJ, Maldera JA, Dematteis A \& Cuasnicu PS 2007 A novel function for CRISP1 in rodent fertilization: involvement in sperm-zona pellucida interaction. Biology of Reproduction 77 848-854. (https://doi. org/10.1095/biolreprod.107.061788)

Cameo MS \& Blaquier JA 1976 Androgen-controlled specific proteins in rat epididymis. Journal of Endocrinology 69 47-55. (https://doi.org/10.1677/ joe.0.0690047)

Carvajal G, Brukman NG, Weigel Muñoz M, Battistone MA, Guazzone VA, Ikawa M, Haruhiko M, Lustig L, Breton S \& Cuasnicu PS 2018 Impaired male fertility and abnormal epididymal epithelium differentiation in mice lacking CRISP1 and CRISP4. Scientific Reports 8 17531. (https:// doi.org/10.1038/s41598-018-35719-3)

Castella S, Fouchécourt S, Teixeira-Gomes AP, Vinh J, Belghazi $M$, Dacheux F \& Dacheux JL 2004 Identification of a member of a new RNase A family specifically secreted by epididymal caput epithelium. Biology of Reproduction 70 319-328. (https://doi.org/10.1095/ biolreprod.103.022459)

Chabory E, Damon C, Lenoir A, Kauselmann G, Kern H, Zevnik B, Garrel C, Saez F, Cadet R, Henry-Berger J et al. 2009 Epididymis selenoindependent glutathione peroxidase 5 maintains sperm DNA integrity in mice. Journal of Clinical Investigation 119 2074-2085. (https://doi. org/10.1172/JCI38940)

Cheng JM, Tang JX, Li J, Wang YQ, Wang XX, Zhang Y, Chen SR \& Liu YX 2018 Role of WNT signaling in epididymal sperm maturation. Journal of Assisted Reproduction and Genetics 35 229-236. (https://doi. org/10.1007/s10815-017-1066-4)

Cho-Vega JH, Vega F, Schwartz MR \& Prieto VG 2007 Expression of dicarbonyl/L-xylulose reductase (DCXR) in human skin and melanocytic lesions: morphological studies supporting cell adhesion function of DCXR. Journal of Cutaneous Pathology 34 535-542. (https://doi. org/10.1111/j.1600-0560.2006.00661.x)

Cohen DJ, Ellerman DA \& Cuasnicú PS 2000 Mammalian sperm-egg fusion: evidence that epididymal protein DE plays a role in mouse gamete fusion. Biology of Reproduction 63 462-468. (https://doi. org/10.1095/biolreprod63.2.462)

Cohen DJ, Ellerman DA, Busso D, Morgenfeld MM, Piazza AD, Hayashi M, Young ET, Kasahara M \& Cuasnicu PS 2001 Evidence that human epididymal protein ARP plays a role in gamete fusion through complementary sites on the surface of the human egg. Biology of Reproduction 65 1000-1005. (https://doi.org/10.1095/ biolreprod65.4.1000)

Conine CC, Sun F, Song L, Rivera-Pérez JA \& Rando OJ 2018 Small RNAs gained during epididymal transit of sperm are essential for embryonic development in mice. Developmental Cell 46 470.e3-480.e3. (https:// doi.org/10.1016/j.devcel.2018.06.024)

Da Ros VG, Maldera JA, Willis WD, Cohen DJ, Goulding EH, Gelman DM, Rubinstein M, Eddy EM \& Cuasnicu PS 2008 Impaired sperm fertilizing ability in mice lacking Cysteine-RIch Secretory Protein 1 (CRISP1). Developmental Biology 320 12-18. (https://doi.org/10.1016/j.ydbio.2008.03.015)

Diao R, Fok KL, Chen H, Yu MK, Duan Y, Chung CM, Li Z, Wu H, Li Z, Zhang $\mathbf{H}$ et al. 2014 Deficient human $\beta$-defensin 1 underlies male infertility associated with poor sperm motility and genital tract infection. Science Translational Medicine 6 249ra108. (https://doi.org/10.1126/ scitranslmed.3009071)

Dorin JR \& Barratt CL 2014 Importance of beta-defensins in sperm function. Molecular Human Reproduction 20 821-826. (https://doi. org/10.1093/molehr/gau050)
Duan S, Shi C, Chen G, Zheng JF, Wu B, Diao H, Ji L, Gu Y, Xin A, Wu Y et al. 2015 Another functional frame-shift polymorphism of DEFB126 (rs11467497) associated with male infertility. Journal of Cellular and Molecular Medicine 19 1077-1084. (https://doi.org/10.1111/ jcmm.12502)

Ernesto JI, Weigel Muñoz M, Battistone MA, Vasen G, Martínez-Lopéz P, Orta G, Figueiras-Fierro D, De la Vega-Beltran JL, Moreno IA, Guidobaldi HA et al. 2015 CRISP1 as a novel CatSper regulator that modulates sperm motility and orientation during fertilization. Journal of Cell Biology 210 1213-1224. (https://doi.org/10.1083/jcb.201412041)

Esch FS, Ling NC, Böhlen P, Ying SY \& Guillemin R 1983 Primary structure of PDC-109, a major protein constituent of bovine seminal plasma. Biochemical and Biophysical Research Communications 113 861-867. (https://doi.org/10.1016/0006-291X(83)91078-1)

Fan J, Lefebvre J \& Manjunath P 2006 Bovine seminal plasma proteins and their relatives: a new expanding superfamily in mammals. Gene $\mathbf{3 7 5}$ 63-74. (https://doi.org/10.1016/j.gene.2006.02.025)

Flower DR 1996 The lipocalin protein family: structure and function. Biochemical Journal 318 1-14. (https://doi.org/10.1042/bj3180001)

Frenette G \& Sullivan R 2001 Prostasome-like particles are involved in the transfer of P25b from the bovine epididymal fluid to the sperm surface. Molecular Reproduction and Development 59 115-121. (https://doi. org/10.1002/mrd.1013)

Gervasi MG \& Visconti PE 2017 Molecular changes and signaling events occurring in spermatozoa during epididymal maturation. Andrology $\mathbf{5}$ 204-218. (https://doi.org/10.1111/andr.12320)

Gibbs GM, Orta G, Reddy T, Koppers AJ, Martínez-López P, de la VegaBeltràn JL, Lo JC, Veldhuis N, Jamsai D, McIntyre P et al. 2011 Cysteinerich secretory protein 4 is an inhibitor of transient receptor potential M8 with a role in establishing sperm function. PNAS 108 7034-7039. (https://doi.org/10.1073/pnas.1015935108)

Girouard J, Frenette G \& Sullivan R 2011 Comparative proteome and lipid profiles of bovine epididymosomes collected in the intraluminal compartment of the caput and cauda epididymidis. International Journal of Andrology 34 e475-e486. (https://doi.org/10.1111/j.13652605.2011.01203.x)

Goswami S, Korrodi-Gregório L, Sinha N, Bhutada S, Bhattacharjee R, Kline D \& Vijayaraghavan S 2019 Regulators of the protein phosphatase PP1 $\gamma 2$, PPP1R2, PPP1R7, and PPP1R11 are involved in epididymal sperm maturation. Journal of Cellular Physiology 234 3105-3118. (https://doi.org/10.1002/jcp.27130)

Grignard E, Morin J, Vernet P \& Drevet JR 2005 GPX5 orthologs of the mouse epididymis-restricted and sperm-bound selenium-independent glutathione peroxidase are not expressed with the same quantitative and spatial characteristics in large domestic animals. Theriogenology 64 1016-1033. (https://doi.org/10.1016/j.theriogenology.2005.01.008)

Guo W, Qu F, Xia L, Guo Q, Ying X \& Ding Z 2007 Identification and characterization of ERp29 in rat spermatozoa during epididymal transit. Reproduction 133 575-584. (https://doi.org/10.1530/REP-06-0301)

Hall JC, Hadley J \& Doman T 1991 Correlation between changes in rat sperm membrane lipids, protein, and the membrane physical state during epididymal maturation. Journal of Andrology 12 76-87.

Hall L, Williams K, Perry AC, Frayne J \& Jury JA 1998 The majority of human glutathione peroxidase type 5 (GPX5) transcripts are incorrectly spliced: implications for the role of GPX5 in the male reproductive tract. Biochemical Journal 333 5-9. (https://doi.org/10.1042/bj3330005)

Hall SH, Yenugu S, Radhakrishnan Y, Avellar MCW, Petrusz P \& French FS 2007 Characterization and functions of beta defensins in the epididymis. Asian Journal of Andrology 9 453-462. (https://doi.org/10.1111/j.17457262.2007.00298.x)

Hamil KG, Liu Q, Sivashanmugam P, Anbalagan $M$, Yenugu S, Soundararajan R, Grossman G, Rao AJ, Birse CE, Ruben SM et al. 2003 LCN6, a novel human epididymal lipocalin. Reproductive Biology and Endocrinology 1 112. (https://doi.org/10.1186/1477-7827-1-112)

Han C, Choi E, Park I, Lee B, Jin S, Kim DH, Nishimura H \& Cho C 2009 Comprehensive analysis of reproductive ADAMs: relationship of ADAM4 and ADAM6 with an ADAM complex required for fertilization in mice. Biology of Reproduction 80 1001-1008. (https://doi.org/10.1095/ biolreprod.108.073700)

Hellsten E, Evans JP, Bernard DJ, Jänne PA \& Nussbaum RL 2001 Disrupted sperm function and fertilin beta processing in mice deficient in the inositol polyphosphate 5-phosphatase Inpp5b. Developmental Biology 240 641-653. (https://doi.org/10.1006/dbio.2001.0476) 
Hoshii T, Takeo T, Nakagata N, Takeya M, Araki K \& Yamamura K 2007 LGR4 regulates the postnatal development and integrity of male reproductive tracts in mice. Biology of Reproduction 76 303-313. (https://doi.org/10.1095/biolreprod.106.054619)

Hu ZH, Liu Q, Shang Q, Zheng M, Yang J \& Zhang YL 2002 Identification and characterization of a new member of serpin family-HongrES1 in rat epididymis. Cell Research 12 407-410. (https://doi.org/10.1038/ sj.cr.7290143)

Hu SG, Du H, Yao GX \& Zhang YL 2012 Molecular cloning and identification of mouse epididymis-specific gene mHong1, the homologue of rat HongrES1. Asian Journal of Andrology 14 626-634. (https://doi.org/10.1038/aja.2011.176)

Hu J, Merriner DJ, O'Connor AE, Houston BJ, Furic L, Hedger MP \& O'Bryan MK 2018 Epididymal cysteine-rich secretory proteins are required for epididymal sperm maturation and optimal sperm function. Molecular Human Reproduction 24 111-122. (https://doi.org/10.1093/ molehr/gay001)

Hutcheon K, McLaughlin EA, Stanger SJ, Bernstein IR, Dun MD, Eamens AL \& Nixon B 2017 Analysis of the small non-protein-coding RNA profile of mouse spermatozoa reveals specific enrichment of piRNAs within mature spermatozoa. RNA Biology 14 1776-1790. (https://doi.org/10.10 80/15476286.2017.1356569)

Ijiri TW, Merdiushev T, Cao W \& Gerton GL 2011 Identification and validation of mouse sperm proteins correlated with epididymal maturation. Proteomics 11 4047-4062. (https://doi.org/10.1002/ pmic.201100075)

Inoue N, Ikawa M, Isotani A \& Okabe M 2005 The immunoglobulin superfamily protein Izumo is required for sperm to fuse with eggs. Nature 434 234-238. (https://doi.org/10.1038/nature03362)

Jalkanen J, Huhtaniemi I \& Poutanen M 2005 Mouse cysteine-rich secretory protein 4 (CRISP4): a member of the Crisp family exclusively expressed in the epididymis in an androgen-dependent manner. Biology of Reproduction 72 1268-1274. (https://doi.org/10.1095/biolreprod.104.035758)

Jalkanen J, Kotimäki M, Huhtaniemi I \& Poutanen M 2006 Novel epididymal protease inhibitors with Kazal or WAP family domain. Biochemical and Biophysical Research Communications 349 245-254. (https://doi.org/10.1016/j.bbrc.2006.08.023)

Kerkhofs S, Dubois V, De Gendt K, Helsen C, Clinckemalie L, Spans L, Schuit F, Boonen S, Vanderschueren D, Saunders PTK et al. 2012 A role for selective androgen response elements in the development of the epididymis and the androgen control of the $5 \alpha$ reductase II gene. FASEB Journal 26 4360-4372. (https://doi.org/10.1096/fj.11-202283)

Kirichok Y, Navarro B \& Clapham DE 2006 Whole-cell patch-clamp measurements of spermatozoa reveal an alkaline-activated $\mathrm{Ca} 2+$ channel. Nature 439 737-740. (https://doi.org/10.1038/nature04417)

Koch S, Acebron SP, Herbst J, Hatiboglu G \& Niehrs C 2015 Posttranscriptional Wnt signaling governs epididymal sperm maturation. Cell 163 1225-1236. (https://doi.org/10.1016/j.cell.2015.10.029)

Krutskikh A, De Gendt K, Sharp V, Verhoeven G, Poutanen M \& Huhtaniemi I 2011 Targeted inactivation of the androgen receptor gene in murine proximal epididymis causes epithelial hypotrophy and obstructive azoospermia. Endocrinology 152 689-696. (https://doi. org/10.1210/en.2010-0768)

Krutskikh A, Poliandri A, Cabrera-Sharp V, Dacheux JL, Poutanen M \& Huhtaniemi I 2012 Epididymal protein Rnase10 is required for posttesticular sperm maturation and male fertility. FASEB Journal $264198-$ 4209. (https://doi.org/10.1096/fj.12-205211)

Lefebvre J, Fan J, Chevalier S, Sullivan R, Carmona E \& Manjunath P 2007 Genomic structure and tissue-specific expression of human and mouse genes encoding homologues of the major bovine seminal plasma proteins. Molecular Human Reproduction 13 45-53. (https://doi. org/10.1093/molehr/gal098)

Lefèvre A, Martin Ruiz C, Chokomian S, Duquenne C \& Finaz C 1997 Characterization and isolation of SOB2, a human sperm protein with a potential role in oocyte membrane binding. Molecular Human Reproduction 3 507-516. (https://doi.org/10.1093/molehr/3.6.507)

Légaré C, Gaudreault C, St-Jacques S \& Sullivan R 1999 P34H sperm protein is preferentially expressed by the human corpus epididymidis. Endocrinology 140 3318-3327. (https://doi.org/10.1210/ endo.140.7.6791)

Li JY, Wang HY, Liu J, Liu Q, Zhang JS, Wan FC, Liu FJ, Jin SH \& Zhang YL 2008 Transcriptome analysis of a cDNA library from adult human epididymis. DNA Research 15 115-122. (https://doi.org/10.1093/ dnares/dsn005)

Lu X, Ding F, Lian Z, Chen L, Cao Z, Guan Y, Chen R, Cai D \& Yu Y 2018 An epididymis-specific secretory protein Clpsl2 critically regulates sperm motility, acrosomal integrity, and male fertility. Journal of Cellular Biochemistry 119 4760-4774. (https://doi.org/10.1002/jcb.26668)

Ma L, Yu H, Ni Z, Hu S, Ma W, Chu C, Liu Q \& Zhang Y 2013 Spink13, an epididymis-specific gene of the Kazal-type serine protease inhibitor (SPINK) family, is essential for the acrosomal integrity and male fertility. Journal of Biological Chemistry 288 10154-10165. (https://doi. org/10.1074/jbc.M112.445866)

Magnuson B, Rainey EK, Benjamin T, Baryshev M, Mkrtchian S \& Tsai B 2005 ERp29 triggers a conformational change in polyomavirus to stimulate membrane binding. Molecular Cell 20 289-300. (https://doi. org/10.1016/j.molcel.2005.08.034)

Maldera JA, Weigel Muñoz M, Chirinos M, Busso D, G E Raffo F, Battistone MA, Blaquier JA, Larrea F \& Cuasnicu PS 2014 Human fertilization: epididymal hCRISP1 mediates sperm-zona pellucida binding through its interaction with ZP3. Molecular Human Reproduction 20 341-349. (https://doi.org/10.1093/molehr/gat092)

Manjunath P 1984 Gonadotropin release stimulatory and inhibitory proteins in bull seminal plasma. In Gonadal Proteins and Peptides and Their Biological Significance, pp 49-61. Eds MR Sairam \& LE Atkinson. Singapore: World Scientific Publishing.

Marcello MR \& Evans JP 2010 Multivariate analysis of male reproductive function in Inpp5b-/- mice reveals heterogeneity in defects in fertility, sperm-egg membrane interaction and proteolytic cleavage of sperm ADAMs. Molecular Human Reproduction 16 492-505. (https://doi. org/10.1093/molehr/gaq029)

Montfort L, Frenette G \& Sullivan R 2002 Sperm-zona pellucida interaction involves a carbonyl reductase activity in the hamster. Molecular Reproduction and Development 61 113-119. (https://doi.org/10.1002/mrd.1137)

Morrison G, Kilanowski F, Davidson D \& Dorin J 2002 Characterization of the mouse beta defensin 1, Defb1, mutant mouse model. Infection and Immunity 70 3053-3060. (https://doi.org/10.1128/iai.70.6.30533060.2002)

Moskovtsev SI, Jarvi K, Légaré C, Sullivan R \& Mullen JB 2007 Epididymal $\mathrm{P} 34 \mathrm{H}$ protein deficiency in men evaluated for infertility. Fertility and Sterility 88 1455-1457. (https://doi.org/10.1016/j.fertnstert.2006.12.053)

Murashima A, Miyagawa S, Ogino Y, Nishida-Fukuda H, Araki K, Matsumoto T, Kaneko T, Yoshinaga K, Yamamura K, Kurita T et al. 2011 Essential roles of androgen signaling in Wolffian duct stabilization and epididymal cell differentiation. Endocrinology 152 1640-1651. (https:// doi.org/10.1210/en.2010-1121)

Nakagawa J, Ishikura S, Asami J, Isaji T, Usami N, Hara A, Sakurai T, Tsuritani K, Oda K, Takahashi M et al. 2002 Molecular characterization of mammalian dicarbonyl/L-xylulose reductase and its localization in kidney. Journal of Biological Chemistry 277 17883-17891. (https://doi. org/10.1074/jbc.M110703200)

Ni Y, Zhou Y, Chen WY, Zheng M, Yu J, Li C, Zhang Y \& Shi QX 2009 HongrES1, a cauda epididymis-specific protein, is involved in capacitation of guinea pig sperm. Molecular Reproduction and Development 76 984-993. (https://doi.org/10.1002/mrd.21063)

Ni MJ, Hu ZH, Liu Q, Liu MF, Lu MH, Zhang JS, Zhang L \& Zhang YL 2011 Identification and characterization of a novel non-coding RNA involved in sperm maturation. PLOS ONE 6 e26053. (https://doi.org/10.1371/ journal.pone.0026053)

Nishimura H, Myles DG \& Primakoff P 2007 Identification of an ADAM2ADAM3 complex on the surface of mouse testicular germ cells and cauda epididymal sperm. Journal of Biological Chemistry 28217900 17907. (https://doi.org/10.1074/jbc.M702268200)

Nixon B, MacIntyre DA, Mitchell LA, Gibbs GM, O'Bryan M \& Aitken RJ 2006 The identification of mouse sperm-surface-associated proteins and characterization of their ability to act as decapacitation factors. Biology of Reproduction 74 275-287. (https://doi.org/10.1095/ biolreprod.105.044644)

Nixon B, De luliis GN, Hart HM, Zhou W, Mathe A, Bernstein IR, Anderson AL, Stanger SJ, Skerrett-Byrne DA, Jamaluddin MFB et al. 2019 Proteomic profiling of mouse epididymosomes reveals their contributions to post-testicular sperm maturation. Molecular and Cellular Proteomics 18 (Supplement 1) S91-S108. (https://doi.org/10.1074/mcp. RA118.000946) 
Noblanc A, Peltier M, Damon-Soubeyrand C, Kerchkove N, Chabory E, Vernet P, Saez F, Cadet R, Janny L, Pons-Rejraji H et al. 2012 Epididymis response partly compensates for spermatozoa oxidative defects in snGPx4 and GPx5 double mutant mice. PLOS ONE 7 e38565. (https:// doi.org/10.1371/journal.pone.0038565)

Nolan MA, Wu L, Bang HJ, Jelinsky SA, Roberts KP, Turner TT, Kopf GS \& Johnston DS 2006 Identification of rat cysteine-rich secretory protein 4 (Crisp4) as the ortholog to human CRISP1 and mouse Crisp4. Biology of Reproduction 74 984-991. (https://doi.org/10.1095/ biolreprod.105.048298)

Oh J, Lee J, Woo JM, Choi E, Park I, Han C, Baek N, Lee H, Kim DH \& Cho C 2006 Systematic identification and integrative analysis of novel genes expressed specifically or predominantly in mouse epididymis. BMC Genomics 7 314. (https://doi.org/10.1186/1471-2164-7-314)

O'Hara L, Welsh M, Saunders PTK \& Smith LB 2011 Androgen receptor expression in the caput epididymal epithelium is essential for development of the initial segment and epididymal spermatozoa transit. Endocrinology 152 718-729. (https://doi.org/10.1210/en.2010-0928)

Orgebin-Crist MC 1967 Sperm maturation in rabbit epididymis. Nature 216 816-818. (https://doi.org/10.1038/216816a0)

Parent S, Lefièvre L, Brindle Y \& Sullivan R 1999 Bull subfertility is associated with low levels of a sperm membrane antigen. Molecular Reproduction and Development 52 57-65. (https://doi.org/10.1002/ (SICI)1098-2795(199901)52:1<57::AID-MRD8>3.0.CO;2-U)

Parks JE \& Hammerstedt RH 1985 Development changes occurring in the lipids of ram epididymal spermatozoa plasma membrane. Biology of Reproduction 32 653-668. (https://doi.org/10.1095/biolreprod32.3.653)

Penttinen J, Pujianto DA, Sipilä P, Huhtaniemi I \& Poutanen M 2003 Discovery in silico and characterization in vitro of novel genes exclusively expressed in the mouse epididymis. Molecular Endocrinology 172138 2151. (https://doi.org/10.1210/me.2003-0008)

Plante G \& Manjunath P 2015 Murine binder of sperm protein homolog 1: a new player in HDL-induced capacitation. Reproduction 149 367-376. (https://doi.org/10.1530/REP-14-0559)

Plante G, Thérien I \& Manjunath P 2012 Characterization of recombinant murine binder of sperm protein homolog 1 and its role in capacitation. Biology of Reproduction 87 20, 1-20, 11. (https://doi.org/10.1095/ biolreprod.111.096644)

Plante G, Thérien I, Lachance C, Leclerc P, Fan J \& Manjunath P 2014 Implication of the human Binder of SPerm Homolog 1 (BSPH1) protein in capacitation. Molecular Human Reproduction 20 409-421. (https:// doi.org/10.1093/molehr/gau006)

Qing X, Shi J, Dong T, Wu C, Hu L \& Li H 2017 Dysregulation of an $\mathrm{X}$-linked primate-specific epididymal microRNA cluster in unexplained asthenozoospermia. Oncotarget 8 56839-56849. (https://doi. org/10.18632/oncotarget.18076)

Reilly JN, McLaughlin EA, Stanger SJ, Anderson AL, Hutcheon K, Church K, Mihalas BP, Tyagi S, Holt JE, Eamens AL et al. 2016 Characterisation of mouse epididymosomes reveals a complex profile of microRNAs and a potential mechanism for modification of the sperm epigenome. Scientific Reports 6 31794. (https://doi.org/10.1038/srep31794)

Rejraji H, Sion B, Prensier G, Carreras M, Motta C, Frenoux JM, Vericel E, Grizard G, Vernet P \& Drevet JR 2006 Lipid remodeling of murine epididymosomes and spermatozoa during epididymal maturation. Biology of Reproduction 74 1104-1113. (https://doi.org/10.1095/ biolreprod.105.049304)

Roberts KP, Wamstad JA, Ensrud KM \& Hamilton DW 2003 Inhibition of capacitation-associated tyrosine phosphorylation signaling in rat sperm by epididymal protein Crisp-1. Biology of Reproduction 69 572-581. (https://doi.org/10.1095/biolreprod.102.013771)

Roberts KP, Ensrud-Bowlin KM, Piehl LB, Parent KR, Bernhardt ML \& Hamilton DW 2008 Association of the protein D and protein E forms of rat CRISP1 with epididymal sperm. Biology of Reproduction 791046 1053. (https://doi.org/10.1095/biolreprod.108.070664)

Rochwerger L \& Cuasnicu PS 1992 Redistribution of a rat sperm epididymal glycoprotein after in vitro and in vivo capacitation. Molecular Reproduction and Development 31 34-41. (https://doi.org/10.1002/ mrd.1080310107)

Ru YF, Xue HM, Ni ZM, Xia D, Zhou YC \& Zhang YL 2015 An epididymisspecific carboxyl esterase CES5A is required for sperm capacitation and male fertility in the rat. Asian Journal of Andrology 17 292-297. (https:// doi.org/10.4103/1008-682X.143314)
Sahu B, Pihlajamaa P, Dubois V, Kerkhofs S, Claessens F \& Jänne OA 2014 Androgen receptor uses relaxed response element stringency for selective chromatin binding and transcriptional regulation in vivo. Nucleic Acids Research 42 4230-4240. (https://doi.org/10.1093/nar/gkt1401)

Schauwaers K, De Gendt K, Saunders PTK, Atanassova N, Haelens A, Callewaert L, Moehren U, Swinnen JV, Verhoeven G, Verrijdt G et al. 2007 Loss of androgen receptor binding to selective androgen response elements causes a reproductive phenotype in a knockin mouse model. PNAS 104 4961-4966. (https://doi.org/10.1073/pnas.0610814104)

Shamsadin R, Adham IM, Nayernia K, Heinlein UA, Oberwinkler H \& Engel W 1999 Male mice deficient for germ-cell cyritestin are infertile. Biology of Reproduction 61 1445-1451. (https://doi.org/10.1095/ biolreprod61.6.1445)

Sharma U, Conine CC, Shea JM, Boskovic A, Derr AG, Bing XY, Belleannee C, Kucukural A, Serra RW, Sun F et al. 2016 Biogenesis and function of tRNA fragments during sperm maturation and fertilization in mammals. Science 351 391-396. (https://doi.org/10.1126/science. aad6780)

Sharma U, Sun F, Conine CC, Reichholf B, Kukreja S, Herzog VA, Ameres SL \& Rando OJ 2018 Small RNAs are trafficked from the epididymis to developing mammalian sperm. Developmental Cell $\mathbf{4 6}$ 481-494.e6. (https://doi.org/10.1016/j.devcel.2018.06.023)

Shum WWC, Ruan YC, Da Silva N \& Breton S 2011 Establishment of cellcell cross talk in the epididymis: control of luminal acidification. Journal of Andrology 32 576-586. (https://doi.org/10.2164/jandrol.111.012971)

Sipilä P, Cooper TG, Yeung CH, Mustonen M, Penttinen J, Drevet J, Huhtaniemi I \& Poutanen M 2002 Epididymal dysfunction initiated by the expression of simian virus 40 T-antigen leads to angulated sperm flagella and infertility in transgenic mice. Molecular Endocrinology 16 2603-2617. (https://doi.org/10.1210/me.2002-0100)

Sonnenberg-Riethmacher E, Walter B, Riethmacher D, Gödecke S \& Birchmeier C 1996 The C-ros tyrosine kinase receptor controls regionalization and differentiation of epithelial cells in the epididymis. Genes and Development 10 1184-1193. (https://doi.org/10.1101/gad.10.10.1184)

Stein KK, Primakoff P \& Myles D 2004 Sperm-egg fusion: events at the plasma membrane. Journal of Cell Science 117 6269-6274. (https://doi. org/10.1242/jcs.01598)

Sullivan R 2015 Epididymosomes: a heterogeneous population of microvesicles with multiple functions in sperm maturation and storage. Asian Journal of Andrology 17 726-729. (https://doi.org/10.4103/1008682 X.155255)

Sullivan R \& Robitaille G 1989 Heterogeneity of epididymal spermatozoa of the hamster. Gamete Research 24 229-236. (https://doi.org/10.1002/ mrd.1120240210)

Sullivan R, Légaré C, Villeneuve M, Foliguet B \& Bissonnette F 2006 Levels of $\mathrm{P} 34 \mathrm{H}$, a sperm protein of epididymal origin, as a predictor of conventional in vitro fertilization outcome. Fertility and Sterility $\mathbf{8 5}$ 1557-1559. (https://doi.org/10.1016/j.fertnstert.2005.10.070)

Suzuki K, Lareyre JJ, Sánchez D, Gutierrez G, Araki Y, Matusik RJ \& Orgebin-Crist MC 2004 Molecular evolution of epididymal lipocalin genes localized on mouse chromosome 2. Gene 339 49-59. (https://doi. org/10.1016/j.gene.2004.06.027)

Tollner TL, Yudin AI, Treece CA, Overstreet JW \& Cherr GN 2008a Macaque sperm coating protein DEFB126 facilitates sperm penetration of cervical mucus. Human Reproduction 23 2523-2534. (https://doi. org/10.1093/humrep/den276)

Tollner TL, Yudin AI, Tarantal AF, Treece CA, Overstreet JW \& Cherr GN $2008 b$ Beta-defensin 126 on the surface of macaque sperm mediates attachment of sperm to oviductal epithelia. Biology of Reproduction $\mathbf{7 8}$ 400-412. (https://doi.org/10.1095/biolreprod.107.064071)

Tollner TL, Venners SA, Hollox EJ, Yudin AI, Liu X, Tang G, Xing H, Kays RJ, Lau T, Overstreet JW et al. 2011 A common mutation in the defensin DEFB126 causes impaired sperm function and subfertility. Science Translational Medicine 3 92ra65. (https://doi.org/10.1126/ scitranslmed.3002289)

Tollner TL, Bevins CL \& Cherr GN 2012 Multifunctional glycoprotein DEFB126 - a curious story of defensin-clad spermatozoa. Nature Reviews: Urology 9 365-375. (https://doi.org/10.1038/nrurol.2012.109)

Tourzani DA, Paudel B, Miranda PV, Visconti PE \& Gervasi MG 2018 Changes in protein O-GlcNAcylation during mouse epididymal sperm maturation. Frontiers in Cell and Developmental Biology 6 60. (https:// doi.org/10.3389/fcell.2018.00060) 
Travis AJ \& Kopf GS 2002 The role of cholesterol efflux in regulating the fertilization potential of mammalian spermatozoa. Journal of Clinical Investigation 110 731-736. (https://doi.org/10.1172/JCI16392)

Turunen HT, Sipilä P, Krutskikh A, Toivanen J, Mankonen H, Hämäläinen V, Björkgren I, Huhtaniemi I \& Poutanen M 2012 Loss of cysteine-rich secretory protein 4 (Crisp4) leads to deficiency in sperm-zona pellucida interaction in mice. Biology of Reproduction 86 1-8. (https://doi.org/10.1095/biolreprod.111.092403)

Vijayaraghavan S, Stephens DT, Trautman K, Smith GD, Khatra B, da Cruz e Silva EF \& Greengard P 1996 Sperm motility development in the epididymis is associated with decreased glycogen synthase kinase- 3 and protein phosphatase 1 activity. Biology of Reproduction 54 709-718. (https://doi.org/10.1095/biolreprod54.3.709)

Wang YM \& Van Eys J 1970 The enzymatic defect in essential pentosuria. New England Journal of Medicine 282 892-896. (https://doi.org/10.1056/ NEJM197004162821604)

Weigel Muñoz M, Battistone MA, Carvajal G, Maldera JA, Curci L, Torres P, Lombardo D, Pignataro OP, Da Ros VG \& Cuasnicú PS 2018 Influence of the genetic background on the reproductive phenotype of mice lacking Cysteine-Rich Secretory Protein 1 (CRISP1). Biology of Reproduction 99 373-383. (https://doi.org/10.1093/biolre/ioy048)

Xu B, Washington AM \& Hinton BT 2014 PTEN signaling through RAF1 proto-oncogene serine/threonine kinase (RAF1)/ERK in the epididymis is essential for male fertility. PNAS 111 18643-18648. (https://doi. org/10.1073/pnas.1413186112)

Yamazaki Y \& Morita T 2004 Structure and function of snake venom cysteine-rich secretory proteins. Toxicon 44 227-231. (https://doi. org/10.1016/j.toxicon.2004.05.023)

Yanagimachi R 1994 Mammalian fertilization. In The Physiology of Reproduction, pp 189-317. Eds E Knobil \& JD Neill. New York: Raven Press.

Yeung CH, Sonnenberg-Riethmacher E \& Cooper TG 1999 Infertile spermatozoa of c-ros tyrosine kinase receptor knockout mice show flagellar angulation and maturational defects in cell volume regulatory mechanisms. Biology of Reproduction 61 1062-1069. (https://doi. org/10.1095/biolreprod61.4.1062)

Yin Q, Shen J, Wan X, Liu Q, Zhou Y \& Zhang Y 2018 Impaired sperm maturation in conditional Lcn6 knockout mice. Biology of Reproduction 98 28-41. (https://doi.org/10.1093/biolre/iox128)

Ying X, Liu Y, Guo Q, Qu F, Guo W, Zhu Y \& Ding Z 2010 Endoplasmic reticulum protein 29 (ERp29), a protein related to sperm maturation is involved in sperm-oocyte fusion in mouse. Reproductive Biology and Endocrinology 8 10. (https://doi.org/10.1186/1477-7827-8-10)
Zhang L, Hu Z, Zhu C, Liu Q, Zhou Y \& Zhang Y 2009 Identification and characterization of an epididymis-specific gene, Ces7. Acta Biochimica et Biophysica Sinica 41 809-815. (https://doi.org/10.1093/abbs/gmp075)

Zhang C, Zhou Y, Xie S, Yin Q, Tang C, Ni Z, Fei J \& Zhang Y 2018 CRISPR/ Cas9-mediated genome editing reveals the synergistic effects of betadefensin family members on sperm maturation in rat epididymis. FASEB Journal 32 1354-1363. (https://doi.org/10.1096/fj.201700936R)

Zhang FP, Malinen M, Mehmood A, Lehtiniemi T, Jääskeläinen $T$, Niskanen EA, Korhonen H, Laiho A, Elo LL, Ohlsson C et al. 2019 Lack of androgen receptor SUMOylation results in male infertility due to epididymal dysfunction. Nature Communications 10 777. (https://doi. org/10.1038/s41467-019-08730-z)

Zhao Y, Diao H, Ni Z, Hu S, Yu H \& Zhang Y 2011 The epididymis-specific antimicrobial peptide $\beta$-defensin 15 is required for sperm motility and male fertility in the rat (Rattus norvegicus). Cellular and Molecular Life Sciences 68 697-708. (https://doi.org/10.1007/s00018-010-0478-4)

Zhou CX, Zhang YL, Xiao L, Zheng M, Leung KM, Chan MY, Lo PS, Tsang LL, Wong HY, Ho LS et al. 2004 An epididymis-specific betadefensin is important for the initiation of sperm maturation. Nature Cell Biology 6 458-464. (https://doi.org/10.1038/ncb1127)

Zhou Y, Zheng M, Shi Q, Zhang L, Zhen W, Chen W \& Zhang Y 2008 An epididymis-specific secretory protein HongrES1 critically regulates sperm capacitation and male fertility. PLOS ONE 3 e4106. (https://doi. org/10.1371/journal.pone.0004106)

Zhou YS, Webb S, Lettice L, Tardif S, Kilanowski F, Tyrrell C, Macpherson H, Semple F, Tennant P, Baker T et al. 2013 Partial deletion of chromosome 8 beta-defensin cluster confers sperm dysfunction and infertility in male mice. PLoS Genetics 9 e1003826. (https://doi.org/10.1371/journal. pgen.1003826)

Zhou W, De Iuliis GN, Dun MD \& Nixon B 2018 Characteristics of the epididymal luminal environment responsible for sperm maturation and storage. Frontiers in Endocrinology 9 59. (https://doi.org/10.3389/ fendo.2018.00059)

Received 19 November 2018

First decision 8 January 2019

Revised manuscript received 29 May 2019

Accepted 6 June 2019 